UDC 004.042;004.5

DOI https://doi.org/10.32838/2663-5941/2019.3-1/34

Furtat I.E.

National Technical University of Ukraine "Igor Sikorsky Kyiv Polytechnic Institute"

Furtat Yu.O.

Pukhov Institute for Modeling in Energy Engineering, NASU

\title{
METHOD OF INCREASING AUTOMATED SYSTEMS' RELIABILITY AND EFFICIENCY USING ADAPTIVE USER INTERFACES AND DOMAIN MODELS BASED ON THE USERS' COGNITIVE CHARACTERISTICS AND WORK PROCESS' SPECIFICS
}

In modern automated systems users are often facing the information overload problem because of ever increasing volumes of information requiring treatment in short time. Working in these conditions affects the system operator's work quality and the systems' reliability. One possible approach to solving the information overload problem is to create personalized interfaces that take into account the user's information management particularities. System operator's features, which determine their preferred information representation shape and pace, form the user's cognitive portrait. Cognitive portrait is built as a result of user interaction with the software diagnostic tools that are based on the cognitive psychology methods. The principles of construction and management of the automated systems' UI (responsible for a form of presenting information to the user) and domain (responsible for a structure of presenting information to the user) models are considered as components of the complex of means for managing user's informational interaction with the automated system management means, adapting this interaction to the user's individual characteristics and work process specifics.

Key words: automated system, informational interaction, user interface, interface adaptation, cognitive portrait, domain model.

Introduction. User interaction with information in the automated system is conducted through system generating an information flow [3-5] that the user perceives and processes (fig. 1).

Based on received information users make some decisions using their own skills and knowledge in long-term memory (LTM), that are transmitted via the user interface to the system, changing its state. Set of UI management elements is determined by the specific workflow tasks and user's characteristics. The flow of information from the system is formed with regard to the user's requests to the system, current workflow step and user interface's output elements through which data will be displayed for the perception and processing of the user. Each of the participants and the elements of information exchange has a number of features, by managing which the process can be adapted to the specific user and the specific situation in the workflow.

Information flow parameters and adaptation. Information flow I from the system can be described as a set of parameters:

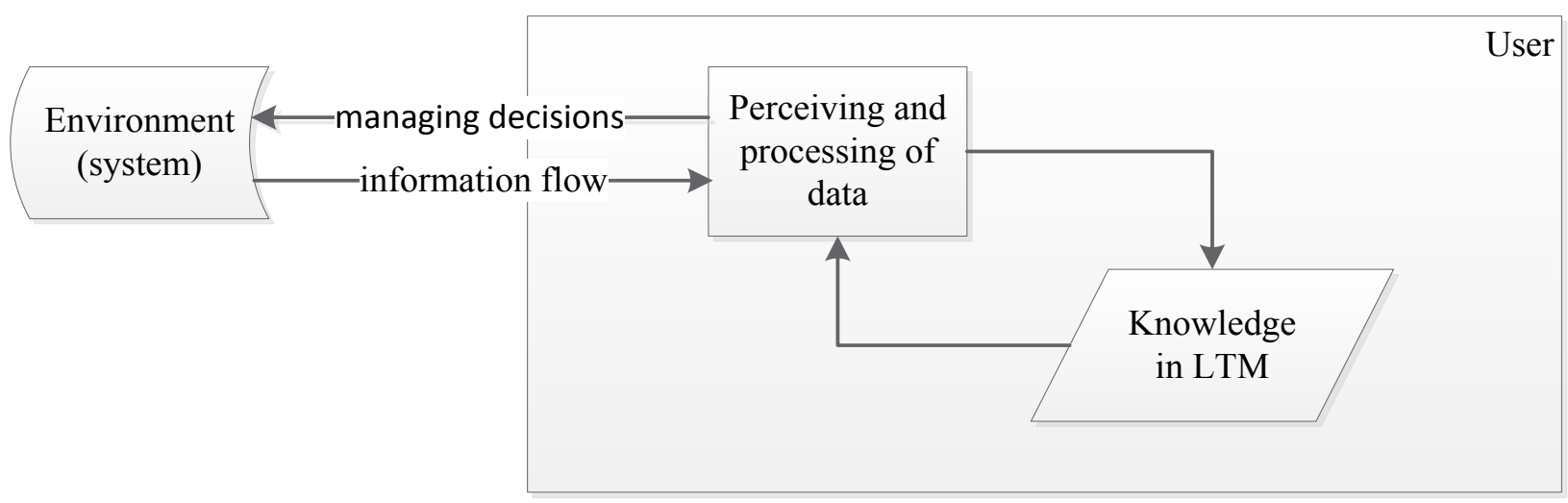

Fig. 1. User-system informational interaction scheme 


$$
I=\langle T, F, C, D\rangle,
$$

$T$ - pace of presentation, $F$ - data format, $C$-information complexity, its connectivity to other blocks of data, $D$ - transmitted data.

Pace of presentation is a qualitative characteristic that can be set to $T=<$ "low", "medium", "high">. The pace of presenting information in automated systems can be managed in non-critical situations by changing the flow intensity depending on the acceptable level of information load. The users' optimal rate is determined by their ability to respond quickly to data from the system, and the current level of fatigue and concentration.

Data format F can be "text", "graphic", "spreadsheet", "audio", "mixed". In general, data format is defined by the user interface's output elements, yet if there is a possibility of changing this set according to users' needs and demands presentation format can also be adapted to the users' characteristics (their cognitive portraits).

The complexity of information - a complex value, which takes into account the links between data blocks in the domain model, the data links amount involved in presenting current portion of data, its overlapping with the user's knowledge model

$$
\mathrm{KM}=\left\langle K_{i},\left\langle c^{j}\right\rangle_{i}\right\rangle, i, j=\overline{1, n},
$$

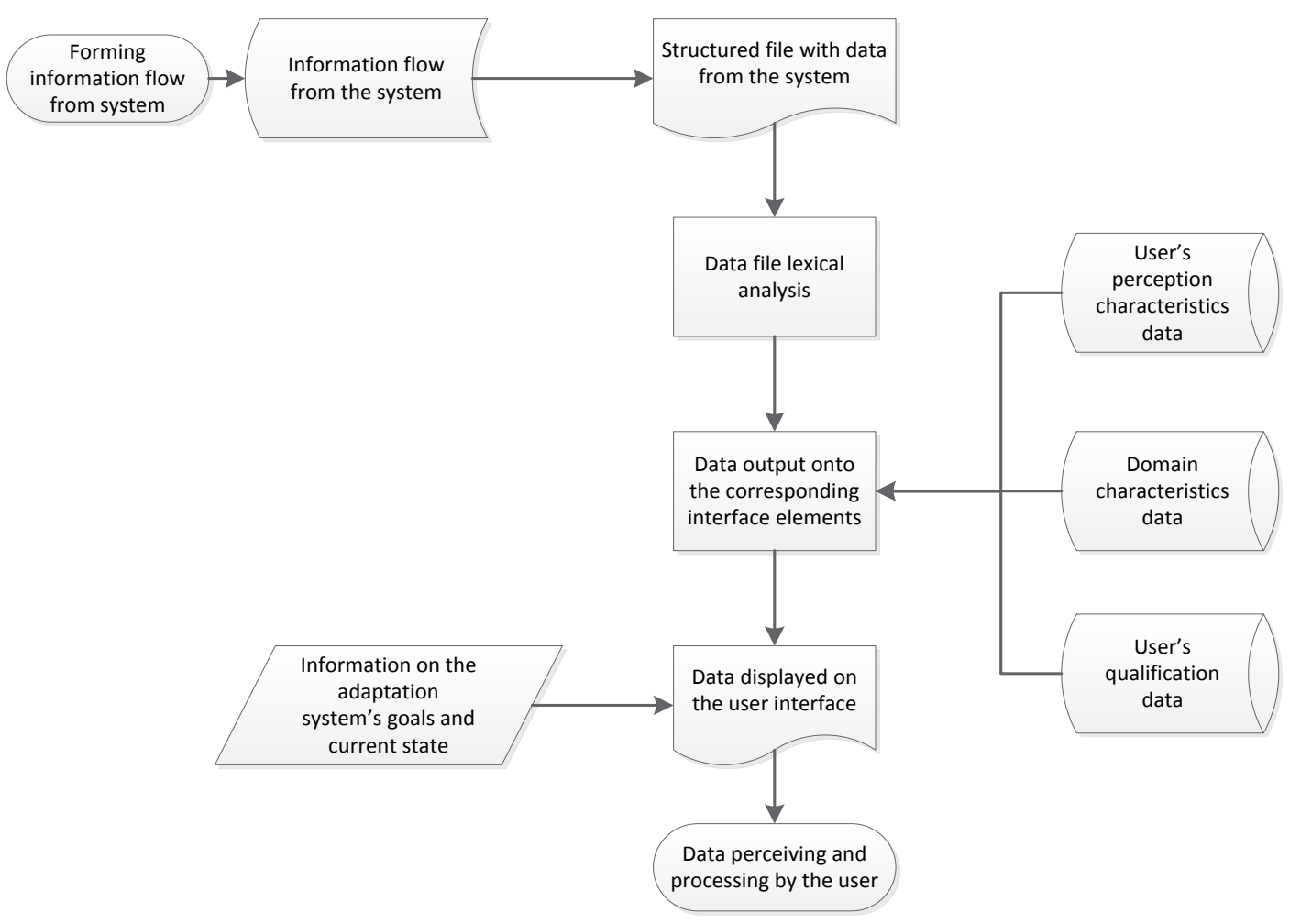

$K_{i}, i=\overline{1, n} \quad-\quad$ domain data blocks, $\left\langle c^{j}\right\rangle_{i}, i=\overline{1, n}, j=\overline{1, n}, j \neq i-\mathrm{i}^{\text {th }}$ data block's connection vector.

Parameter D is a portion of data transferred to the user in the particular workflow episode. This portion may correspond to one domain data block or it may consist of a set of blocks or a part of a single block, depending on the user-system interaction script.

In most modern automated systems user-system interaction is defined by the following algorithm (fig. 2).

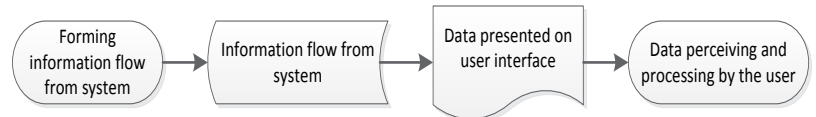

Fig. 2. User-system information interaction

To perform information exchange adaptation the algorithm in fig. 1 should be modified to allow consideration of specific users' and workflows' characteristics.

As adaptation criterion the users' cognitive portraits are considered, as adaptation object - data presentation form and pace (information flow characteristics).

If the user-system informational interaction process's adaptation and personalization is considered as controlling parameters of an information flow (1), we obtain a modified information exchange, shown in fig. 3 .

Fig. 3. Adapted user-system information interaction 
Information exchange adaptation and personalizing is performed at the stage of information flow's forming (managing parameters $\mathrm{T}$ and $\mathrm{C}$ of model (1)) and at the stage of data output through user interface (managing parameter F). Information flow's parameter $\mathrm{D}$ depends on the specifics of the overall workflow, and on the current users' specific goals.

Managing data output through personalized user interface. User interface in automated systems is considered as a set of elements $U I=\left\langle E_{i}\right\rangle, i=\overline{1, n}$, each output element

$$
E_{i}=\left\langle\langle x, y\rangle_{i}^{j}, T_{i}, c_{i}\right\rangle, j=\overline{1, m},
$$

$\langle x, y\rangle_{i}^{j}$ - output element's corner coordinates; $T_{i}-i^{\text {th }}$ element's output type; $c_{i}-i^{\text {th }}$ element's weight (importance) for the user.

The set of values of $T_{i}$ in model (3) coincides with the set of values of parameter $F$ in model (1), and it is the type of available output elements which determines the preferred output data format on the information flow's formation stage.

Output element's weight is defined by the workflow's specifics. Critical elements display information, loos of which to disruption of the workflow or inability for the user to correctly process information from the system.

Managing output elements' position and type allows creating personalized user interface for adapting the user-system information interaction. Critical output elements output must be present in the user interface, regardless of its adaptation.

Desired output element types are defined by the users' cognitive portraits' characteristics.

Cognitive portrait is a set of user characteristics.

$$
C P=\left\langle\left\langle\operatorname{Cog}_{i}\right\rangle,\left\langle P P_{j}\right\rangle,\left\langle\operatorname{Int}_{k}\right\rangle\right\rangle, i=\overline{1, m}, j=\overline{1, n}, k=\overline{1, p},
$$

$\operatorname{Cog}_{i}-$ cognitive users' characteristics; $P P_{j}-$ physiological characteristics; Int $_{k}$ - intellectual characteristics.

Cognitive portrait's characteristics define optimal for on-screen data presentation number, type and relative position of user interface output elements.

These characteristics are divided into cognitive, physiological and intellectual.

Cognitive characteristics largely determine the speed at which the user is guided in the new information and switch between different types of activities. They are field dependence, equivalence range, impulsiveness and intellectual lability.

For each of these characteristics within cognitive psychology have been developed appropriate diagnostic techniques, many of which are sufficiently formalized to be implemented as a part of the automated characteristics diagnostic subsystem.
To assess the psychophysiological state of the user often are uses options such as his attitude to risk, quality of memory and attention. In this case, the testing impact reaction time and the responses errors should allow to evaluate concentration and coordination of user actions, because these depend on personal characteristics [1].

Intelligent features include the level of IQ and EQ (intelligence and emotional intelligence quotient, respectively) [2]. Although the coefficient of emotional intelligence is associated with the value of IQ, there is no direct relationship, namely the value of EQ determines predisposition to creativity when working with information. This characteristic is very important for users of design and training systems.

Nowadays cognitive portraits of the automated systems users are created based on professional psychological testing. But this method has two major drawbacks. First, it requires the participation of a professional psychologist, and the number of automated systems and their operators is growing faster than in an equal number of professional psychologists can be prepared. Secondly, this testing is not operational, it is a separated from the user's work process and workplace.

Both of these drawbacks can be eliminated by introducing an automatic testing subsystem into the interface adaptation system. Scheme of a possible implementation of this subsystem is shown in Fig. 4.

User testing is conducted both explicitly (during performing of tests) and in the background when on the computer workstations are monitored indicators such as speed of action or response to the changing situation. In both cases, user characteristics information is treated by a separate testing system module and supplements or modifies an initial cognitive profile that is used for further user interface management system work. This way - through modifying user interface and observing the performance changes with it (which is reflected in increasing responsiveness and reducing the number of errors when dealing with information) can the finite number of steps of the iterative process be taken to optimize the form of the interface for a particular user (in the case of interfaces with automatic adjustment).

Using domain knowledge model to manage information storage form. To enable further flexible information interaction adaptation it is advisable to manage not only presentation form, but the pace and intensity of information flow. This requires the ability to manage blocks of information, knowledge system organization, personalized learning programs.

Existing knowledge communications systems can be characterized by four basic components: expert 


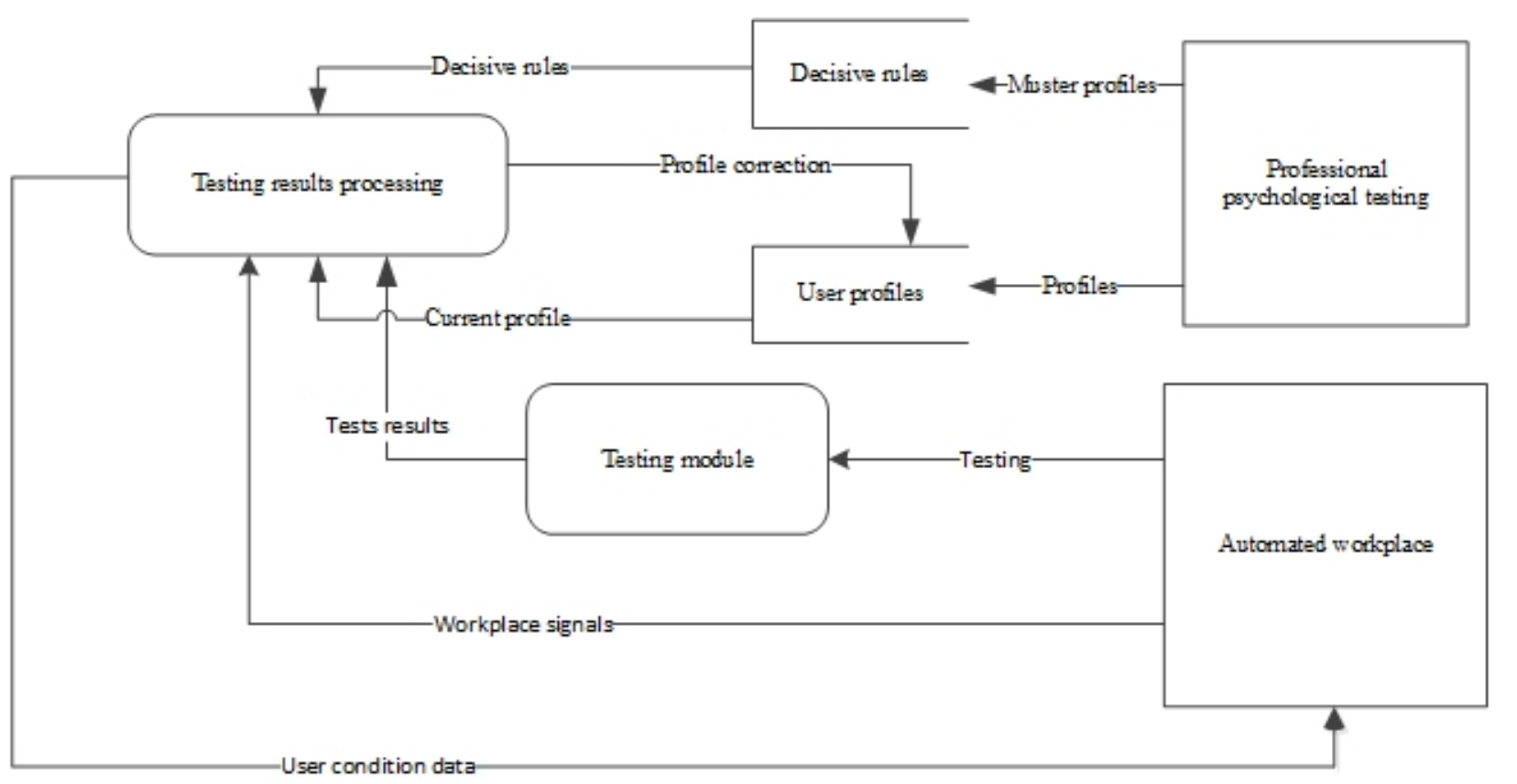

Fig. 4. Users' characteristics' diagnostics system

domain knowledge (domain model); user model; expert knowledge of teaching method (interaction script); user-system interface.

Knowledge model (2) performs a dual function. On the one hand it is a source of domain knowledge that is provided to the user in portions, on the other it sets the desired standard for the users' current knowledge level evaluation. Domain model has an important place in the process of scripting user interaction with the information and in the management of information flow characteristics within decision-making metascript in automated systems. In automated learning systems knowledge models are connected to the discipline's lesson plan, which provides both the knowledge blocks' contents and the order in which the users access these bloks.

User model is generally an incomplete modified model domain knowledge model (2) and is designed mainly to anticipate users' behavior for its interpretation. The ideal user model must make accurate predictions of the behavior of any user in any domain context. For example, a set of possible responses to a block of data from the system.

With the user model's concept a diagnostic process is often associated - adapting the user model based on the data obtained through user-system dialog. In automated learning systems prior progress checks' results for particular students can be used - providing information regarding learning course segments work should be currently focused on.

Interaction script determines which piece of data and at what time will be transmitted to the user. In the most general case the interaction script is not hard coded and is derived based on the current situation and the deduction method, stored as a set of principles or rules. The adaptation is based on predicting users' responses, generated by user models, users' real reaction and relations between the workflow episodes stored in the domain model.

Interaction scripts may vary in relation to the degree of "freedom" given to the user, and can range between two extremities: full control of all user actions and guiding users through workflow episodes workflow - or complete freedom of user's navigational activity and giving requests-based recommendations.

Fig. 5 illustrates relationship between these four basic concepts of knowledge communication.

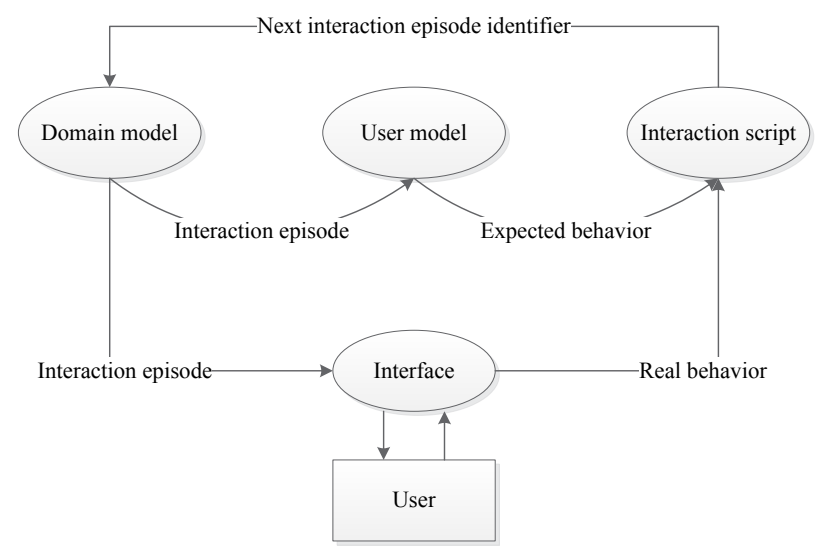

Fig. 5. Basic concepts of knowledge communication systems 
User system interaction's script construction and modification takes into account the interaction script, based on the users' model and their actual behavior when processing previous information blocks taken from the domain model.

Conclusion. By using models of user interface, users' cognitive portraits, domain and users' knowledge is it possible to perform flexible adaptation and personalization of user-systems interface. Such adap- tation involves modifying not only data presentation, but also data storage and he script of the interaction itself based on the workflow specifics and the users' preferences. This results in fewer mistakes when perceiving and processing information and lower stress levels for the users. When used in the learning process, such adaptation and personalization allow to improve both testing and studying efficiency for each particular student.

\section{References:}

1. Верлань А.Ф. Особенности оперативного тестирования на рабочем месте операторов систем поддержки принятия решений (СППР) / Верлань А.Ф., Сопель М.Ф., Фуртат Ю.О. Математичне та комп'ютерне моделювання. Серія: Технічні науки : Збірник наукових праць Інституту кібернетики імені В.М. Глушкова НАН України та Кам’янець-Подільського національного університету ім. Івана Огієнка. Кам'янець-Подільський : Кам'янець-Подільський національний університет ім. Івана Огієнка. 2010. Вип. 3. С. $37-45$.

2. Немов Р.С. Психология : Учебник для студ. высш. пед. учеб. Заведений : В 3 кн. Изд. 4-ое Москва: Гуманит. изд. центр ВЛАДОС, 2003. Кн. 1 : Общие основы психологии. 688 с.

3. Furtat Yu.O. Functional basis of means of the automated systems' user interfaces' adaptation to the user's cognitive characteristics / Furtat Yu.O. Mathematical and computer modelling. Series: Technical sciences. Scientific digest of V.M. Glushkov Institute of Cybernetics of the National Academy of Sciences of Ukraine and Kamianets-Podilskyi National Ivan Ohiienko University. Kamianets-Podilskyi : Kamianets-Podilskyi National Ivan Ohiienko University. 2013. Iss. 8. P. 120-131.

4. Gadezka Z.M. Development of object-oriented models of visual attention / Gadezka Z.M., Nagornii V.A., Zhiriakova I.A. Proceedings of International Scientific Conference "Modern management in production and humanitarian activity", 5-6th of April, 2005. Cherkassy : East-European University of Economics and Management; 2005. P. 39.

5. Us M.F. Onthological approaches to evaluation of the listener's cognitive level in conditions of "electronic" education / Us M.F., Gadezka Z.M., El-Murr P.A. Modeling and informational technologies. Scientific digest of Pukhov Institute for Modelling in Energy Engineering. Kyiv, 2006. Iss. 38. P. 150-155.

\section{МЕТОД ПІДВИЩЕННЯ НАДІЙНОСТІ ТА ЕФЕКТИВНОСТІ АВТОМАТИЗОВАНИХ СИСТЕМ ІЗ ВИКОРИСТАННЯМ АДАПТИВНИХ ІНТЕРФЕЙСІВ КОРИСТУВАЧА ТА МОДЕЛЕЙ ДОМЕНІВ, ЗАСНОВАНИХ НА ОСОБЛИВОСТЯХ ПІЗНАННЯ КОРИСТУВАЧІВ ТА СПЕЦИФІЦІ РОБОЧОГО ПРОЦЕСУ}

В сучасних автоматизованих системах користувачі часто стикаються з проблемою інформачійних перевантажень через постійно зростаючі обсяги інформації, щуо потребують обробки в короткий термін. Робота в ицих умовах впливає на якість роботи оператора системи та надійність систем. Одним із можливих підходів до вирішення проблеми перевантаження інформаиії є створення персоналізованих інтерфейсів, які враховують особливості роботи користувача з інформачією. Особливості опператора системи, які визначають форму подання інформачї та ї̈ темп, визначають когнітивний портрет користувача. Когнітивний портрет будується в результаті взаємодії користувача з програмними засобами діагностики, що трунтуються на методах когнітивної психології. Принципи побудови та управління інтерфейсом автоматизованих систем (відповідає за форму представлення інформації користувачеві) та доменної моделі (відповідає за структуру подання інформачії користувачу) розглядаються як компоненти комплексу засобів управління інформачійною взаємодією користувача з засобами автоматизованої системи управління, адаптуючи иъю взаємодію до індивідуальних особливостей користувача та специфіки робочого процесу.

Ключові слова: автоматизирована система, інформаційна взаємодія, користувацький інтерфейс, адаптація інтерфейсу, когнітивний портрет, доменна модель. 


\section{МЕТОД ПОВЫШЕНИЯ НАДЕЖНОСТИ И ЭФФЕКТИВНОСТИ АВТОМАТИЗИРОВАННЫХ СИСТЕМ С ИСПОЛЬЗОВАНИЕМ АДАПТИВНЫХ ПОЛЬЗОВАТЕЛЬСКИХ ИНТЕРФЕЙСОВ И МОДЕЛЕЙ ПРЕДМЕТНОЙ ОБЛАСТИ, ОСНОВАННЫХ НА КОГНИТИВНЫХ ХАРАКТЕРИСТИКАХ ПОЛЬЗОВАТЕЛЕЙ И ОСОБЕННОСТЯХ РАБОЧЕГО ПРОЦЕССА}

В современных автоматизированных системах пользователи часто сталкиваются с проблемой информащионной перегрузки из-за постоянно растущих объемов информащии, требующих обработки в короткие сроки. Работа в этих условиях влияет на качество работы оператора системы и надежность системы. Одним из возможных подходов к ремению проблемы информачионной перегрузки является создание персонализированных интерфейсов, учитывающих особенности пользователя по работе с информачией. Особенности оператора системы, которые определяют предпочтительную форму и темп представления информачии, формируют когнитивный портрет пользователя. Когнитивный портрет строится в результате взаимодействия пользователя с программными средствами диагностики, основанныли на методах когнитивной психологии. Принципы построения и управления моделями пользовательского интерфейса автоматизированных систем (ответственных за форму представления информачии пользователю) и доменных моделей (отвечающих за структуру представления информации пользователю) рассматриваются как компоненты комплекса средств управления информационным взаимодействием пользователя со средствами управления автоматизированной системой, адаптируюшие это взаимодействие к индивидуальным характеристикам пользователя и особенностям рабочего проиесса.

Ключевые слова: автоматизированная система, информачионное взаимодействие, пользовательский интерфейс, адаптация интерфейса, когнитивный портрет, доменная модель. 